\title{
POLA INTERAKSI HARMONIS ANTARA MITOS, SAKRAL, DAN KEARIFAN LOKAL MASYARAKAT PASURUAN
}

\author{
Agus Zaenul Fitri \\ Sekolah Tinggi Agama Islam Negeri Tulungagung \\ Jalan Mayor Sujadi Timur No. 46 Tulungagung, email:guszain@yahoo.co.id
}

\section{Abstract}

The charges with covert mission in terms of local wisdom such as mysticism, sacralization, Javanese and ancestor gods are exaggerated perspective. Through Anthropological studies of sacred, mythology and local wisdom is elaborated on the meaning and relevance to the public ritual actions in Pasuruan Regency with the attempt to build harmony and interaction between local culture and Islam. This study focused on the dynamical of relationship between religion and social religious culture interactions among groups in society through religious symbols system. Every religious tradition includes sacred symbols with which the person conducting a series of measures to shed beliefs in the form of ritual, reverence and servitude. Hindu communities in the mountains Pasuruan region have been driven to assimilate with Muslim population. But the religion which is embraced by the majority of the population are nominal Muslims, but confounds the Tengger and Javanese-style ritual, because the vast majority of Muslims there refused to form a more strict Islamic piety is identified with a culture that does not fit to the culture of Java, in contrast to Muslims Pasuruan in the lowlands because much dominated by the descendants of Madura, the Islamization can continue to do without having to harm the local culture, which in turn would foster against-Islam movement.

Tuduhan terhadap misi terselubung dalam istilah kearifan lokal seperti mistisisme, sakralisasi, kejawen, dan sesembahan lelulur merupakan cara pandang yang berlebihan. Melalui studi Antropologi tentang sakralisasi, mitologi, dan kearifan lokal ini dipaparkan makna dan relevansinya terhadap tindakan ritual masyarakat kabupaten Pasuruan dengan upaya membangun wajah dalam harmoni dan interaksi antara budaya lokal dan Islam. Kajian 
ini menitikberatkan pada dinamika hubungan antara agama dan berbagai kelompok sosio religio kultural melalui interaksi antar kelompok di dalam masyarakat melalui simbol-simbol religius. Setiap tradisi keagamaan memuat simbol-simbol suci yang dengannya orang melakukan serangkaian tindakan untuk menumpahkan keyakinan dalam bentuk melakukan ritual, penghormatan dan penghambaan. Masyarakat Hindu di wilayah Pasuruan pegunungan telah terdorong untuk berasimilasi dengan penduduk muslim. Namun agama Islam yang dipeluk oleh sebagian besar penduduk adalah Islam nominal namun mencampur adukkan gaya ritual Tengger dan Kejawen, karena mayoritas Muslim di sana menolak bentuk kesalehan Islam yang lebih ketat yang diidentifikasi dengan kebudayaan yang tidak njawani, berbeda dengan muslim pasuruan di dataran rendah karena banyak didominasi oleh keturunan Madura, maka Islamisasi dapat terus dilakukan tanpa harus mencederai kebudayaan lokal yang pada akhirnya justru menyuburkan gerakan anti-Islam.

Key words: myth, sacred, local wisdom, interaction, harmonization

\section{Pendahuluan}

Kearifan lokal merupakan proses yang sangat lama dan kemudian menjadi sebuah acuan filosofis dan pegangan hidup masyarakat. Namun bukan berarti itu adalah sebuah dogma yang tidak bisa berubah, karena tidak ada yang kekal di dunia ini kecuali perubahan itu sendiri. Kearifan lokal perlu dilihat sebagai "nilai luhur" (lofty value), tidak hanya memandangnya sebagai masalah benar atau salah, namun jauh lebih penting adalah melihat kebaikan (not the truth but what's the good).

Relasi antara sakralisasi, mistisisme dan kearifan lokal tampak berjalan secara harmonis dalam masyarakat Jawa, sebagaimana ditunjukkan dalam keselarahan hidup masyarakat Tengger khususnya dan Kabupaten Pasuruan pada umumnya. Terdapat pandangan negatif dengan mengatakan bahwa istilah kearifan lokal merupakan istilah mistisisme yang terselubung, karena amat dekat dengan mistisisme kuno seperti kejawen, ajaran nenek moyang dan sesembahan leluhur. Gagasan kearifan lokal adalah sisipan dari Mason Melayu yang mengacu pada kebijaksanaan peninggalan kuno (ancient wisdom). Islam dapat diterima dengan baik dalam masyarakat Jawa memang melalui proses akulturasi budaya yang telah berevolusi selama ratusan tahun. Relasi budaya telah membangun harmonisasi di antara kepercayaan-kepercayaan yang ada, baik atas dasar agama maupun kepercayaan terhadap mistis dan roh leluhur. Islam hadir tidak dengan mencederai budaya lokal manapun, tetapi berasimilasi di tengah budaya yang beragam dengan penuh dinamika 
melalui local wisdom (Artawijaya, 2010: 36).

Bahasan-bahasan ilmiah mengenai masyarakat Jawa selalu mengaitkan keberagamaan dalam ortodoksi Islam dengan perbedaan sosio ekonomi, kelas, perilaku politik, dan konflik sosial. Dalam rumusan sosiologis yang paling dikenal luas, membedakan tiga macam Islam Jawa dan menghubungkan dengan sesuatu kelas sosial tertentu (Geertz, 1981: 20). Tradisi abangan digambarkan sebagai campuran sinkretik dari unsur animisme, Hindu Budha dan Islam yang menonjol di kalangan masyarakat pedesaan Jawa. Tradisi santri diidentifikasi sebagai varian Islam yang lebih ortodoks, terutama tersebar luas dikalangan para pedagang dan petani kaya. Akhirnya, tradisi priyayi diidentifikasi sebagai suatu warisan elite yang sangat dipengaruhi oleh nilai-nilai Hindu Budha keraton Jawa sebelumnya dan berkaitan dengan golongan bangsawan tradisional Jawa dan Birokrasi pemerintahan yang menggantikannya pada era modern (Koentjoroningrat, 1985: 316).

Pengkajian kembali secara menyeluruh terhadap tipologi Geertz akan menghasilkan sebuah tulisan yang terpisah, tetapi di sini perlu dicatat beberapa hal. Pertama, sebagaimana telah disebut secara luas, penggunaan Geertz terhadap istilah priyayi tidak sesuai dengan penggunaan Jawa, di mana istilah tersebut mengacu kepada pembedaan kelas sosial (priyayi dipertentangkan dengan wong cilik), bukan kebudayaan keagamaan. Beberapa priyayi adalah muslim yang shaleh. Kedua, terkait dengan pokok pertama, perbedaan antara Muslim Jawa dan Muslim ortodoks cenderung lintas kelas ketimbang dengan rapi berhubungan dengannya. Karenanya, ada petani dan aristokrat yang santri dan yang lain adalah Muslim Jawa. Namun, hubungan yang erat dari status kelas atau ekonomi dan orientasi keagamaan ditemukan di kalangan para pedagang, sebagaimana seluruh Indonesia yang cenderung menjadi lebih ortodoks (Dhofier, 1982: 91-92; Boland, 1982: 4).

Di samping itu, keseluruhan isu mengenai agama dan kelas diperumit oleh variasi daerah. Wilayah “jantung” Jawa Tengah bagian Selatan (termasuk bagian barat Propinsi Jawa Timur) cenderung menjadi kantong kejawen, sementara ortodoksi Islam terutama kuat di bagian barat Jawa Tengah (perbatasan dengan Sunda), Pantai Utara dan wilayah penting bagian Timur yang dipengaruhi Madura dan ujung Jawa Timur, telah mencatat bahwa variasi daerah dalam keseimbangan kejawen dan Islam ortodoks sama pentingnya dengan variasi menurut status ekonomi mencatat hal serupa bahwa hubungan antagonistik yang betul-betul disadari antara orang-orang kejawen dan santri baru muncul sejak abad ke-19, ketika kebangkitan Islam yang direvitalisasikan memaksa 
banyak orang Jawa untuk mempertimbangkan kembali identitas mereka sebagai Muslim dan orang Jawa. Jelas hubungan tersebut telah mengalami ketegangan baru pada awal masa kemerdekaan, sementara ingatan terhadap peristiwa Madiun "sangat mempertajam" ketegangan antara Kejawen dan Muslim Ortodoks di Mojokuto (Ricklefs, 2002: 115).

\section{Tradisi dalam Masyarakat Jawa}

Masyarakat Jawa dengan budayanya sangat lekat sekali dengan kepercayaan yang penuh dengan mitologisasi (memitoskan), sakralisasi (mengkeramatkan), dan mistifikasi (memandang sesuatu sebagai misteri). Kesemuanya itu merupakan mitologi yang dapat ditemukan pada orang, tempat, waktu dan peristiwa. Hal terlihat dalam nama, kelahiran, waktu, huruf, angka dan keberuntungan. Realitas mitos Jawa tersebut termanifestasi melalui bentuk upacara ritual. Mengetahui mitos adalah sesuatu yang penting karena mitos tidak hanya mengandung tafsiran tentang dunia dengan segala isinya dan contoh model tentang keberadaannya di dunia. Sehingga mitos bagi masyarakat Jawa bukan merupakan pemikiran intelektual dan bukan pula hasil logika, melainkan lebih merupakan orientasi spiritual dan mental untuk berhubungan dengan Tuhan.

Konteks kajian antropologi menjelaskan bahwa upacara memiliki dua aspek, yaitu ritual dan seremonial. Ritual menurut Winnick adalah a set or series of acts, usually involving religion or magic, with the sequence establish by tradition... they often stem from the daily life..... Ritual adalah seperangkat tindakan yang selalu melibatkan agama atau magi, yang dimantapkan melalui tradisi. Ritus tidak sama persis dengan pemujaan, karena ritus meliputi: ritus kelahiran, ritus fertilitas, ritus inisiasi, ritus kesehatan, ritus purifikasi dan ritus transisi. Menurut Van Gennep, ritus tersebut meliputi sekitar sampainya periode kelahiran, pubertas, perkawinan, dan kematian. Baginya, ada klasifikasi tripartite, yaitu: ritus yang menjadi bagian seseorang dari asosiasi terdahulu, ritus untuk mempersiapkan pada periode marginal dan ritus untuk agregasi yang penyatuannya dengan eksistensi baru (Syam, 2005: 16).

A fixed or sanctioned pattern of behavior which surrounds various phases of life, often serving religious or aesthetic ends confirming the groups's celebration of particular situation. Jadi, seremoni merupakan sebuah pola tetap dari tingkah laku yang terkait dengan variasi tahapan kehidupan, tujuan keagamaan atau estetika dan menguatkan perayaan didalam kelompok di dalam situasi yang partikular. Misalnya, upacara animal renewing, morning star (upacara pengorbanan 
anak muda pada bintang pagi di Pawnee), new fire (upacara orang Aztek di altar api), dan sebagainya (Winnick, 1977: 461).

Banyak ahli telah memberikan batasan mengenai ritual. Diantaranya adalah Alexander, memberikan definisi ritual tradisional adalah "membuka keteraturan kehidupan kearah realitas tak terbatas atau kenyataan transcendental atau kekuatan untuk mengambil kekuasaan transformatif." (Bowie, 2000: 153). Lainnya, Gluckman menyatakan bahwa "upacara sebagai kumpulan aktivitas manusia yang kompleks dan tidak mesti bersifat teknik atau rekreasional, tetapi melibatkan model perilaku yang sepatutnya dalam suatu hubungan sosial, sedangkan ritual adalah kategori upacara yang lebih terbatas, tetapi secara simbolis lebih kompleks karena menyangkut urusan sosial dan psikologis yang lebih dalam. Ritual dicirikan mengacu pada sifat dan tujuan mistis (Muhaimin, 2001: 114).

Mengikuti Geertz, Durkheim dan Robertson Smith, menyebutkan bahwa di dalam melihat ritual, dia lebih menekankan pada bentuk ritual sebagai penguatan ikatan tradisi sosial dan individu dengan struktur sosial dari kelompok. Integrasi itu dikuatkan dan diabadikan melalui simbolisasi ritual atau mistik. Jadi ritual dilihat sebagai perwujudan esensial dari kebudayaan. Lebih lanjut dinyatakan bahwa ritual adalah as dramatizing the basic myths and vision of reality, the basic values and moral truths, upon which...the world rest (Dirks, 1994: 484). Senada dengan pernyatan ini, Dhavamony, juga menyatakan bahwa upacara ialah "setiap organisasi kompleks apa pun dari kegiatan manusia yang tidak hanya bersifat sekedar teknik atau rekreasional, dan berkaitan dengan penggunaan cara-cara tindakan yang ekpresif dari hubungan sosial (Syam 2005: 19).

Ritual selanjutnya adalah suatu kenyataan bahwa ia melibatkan pengertian mistis.” Dengan demikian, perbedaan di antara keduanya ialah pada aspek bentuk tindakannya yang melibatkan sesuatu yang mistik atau tidak. Ritual dibedakan menjadi empat macam, yaitu: (1) tindakan magis, yang dikaitkan dengan penggunaan bahan-bahan yang bekerja karena daya-daya mistis, (2) tindakan religius kultus para leluhur, juga bekerja dengan cara ini; (3) ritual konstitutif yang mengungkapkan atau mengubah hubungan sosial dengan merujuk pada pengertian-pengertian mistis, dengan cara ini upacara-upacara kehidupan menjadi khas, (4) ritual faktitif yang meningkatkan produktivitas atau kekuatan, atau pemurnian dan perlindungan, atau dengan cara lain meningkatkan kesejahteraan materi suatu kelompok (Dhavamony, 2000: 175).

Melalui pengkategorian ini, semua etnis memiliki upacara. Berbagai

el Harakah Vol.14 No.1 Tahun 2012 
kajian telah dilakukan oleh ahli antropologi, misalnya E.B Taylor dan R.R Marett. Teori tentang magi juga ditemukan oleh Malinowsky di dalam penelitiannya di Trobrian. Jika Frazer lebih mengarahkan perhatiannya kepada persoalan bagaimana magi itu ada dan berkembang di masyarakat primitif, maka Malinowsky lebih mengarahkan perhatiannya pada bagaimana magi bisa bersanding dengan agama dan ilmu. Jika magi adalah manusia menggunakan kekuatan gaib untuk memperoleh tujuannya, agama lebih merupakan kepatuhan kepada kekuatan gaib untuk melakukan apa yang diperintahkan (Baal, 1995: 21; Koenjoroningrat, 1985: 42).

Berbagai tulisan tentang ritual di Jawa, diilhami oleh karya Geertz yang berjudul "Abangan, Santri, Priyayi dalam Masyarakat Jawa". Di antara mereka yang menjadikan konsepsi mengenai hubungan antara Islam dan budaya lokal yang bercorak sinkretik sebagai sesuatu yang benar adanya, misalnya sinkretisme tersebut tampak dalam berbagai upacara yang diselenggarakan oleh masyarakat Jawa. Terutama slametan. Slametan baginya ialah agreeing to differ, sebab meskipun mereka datang dari berbagai variasi sosio religious kultural yang berbeda ternyata mereka menghadiri ritual ini (Beatty, 2001: 39-40).

\section{Islam Lokal: Interaksi dan Harmonisasi Kehidupan Keagamaan}

Kajian yang menempatkan masyarakat lokal dalam merespon agama atau pengaruh budaya lokal terhadap pemahaman keagamaan sebagai fokus keagamaan, misalnya Geertz dengan topik Abangan, Santri, Priyayi dalam Masyarakat Jawa, pada pertengahan tahun 1950an di Mojokuto Jawa Timur. Penelitian telah dibukukan berjudul The Religion of Java. Tulisan ini sebagaimana judul aslinya memberikan gambaran bahwa masyakat Jawa memiliki agama sendiri, yaitu agama lokal yang berisi kepercayaan terhadap numerologi, kekuatan gaib dan berikut tradisi ritualnya, yang diidentikkan dengan kepercayaan kaum abangan yang terkonsentrasi di wilayah pedesaan Jawa (Geertz, 2005: 23). Di sisi lain, juga terdapat kaum santri yang memiliki keyakinan kuat terhadap agama Islam dan terbagi menjadi dua ialah kaum modernis (Muhammadiyah) dan kaum tradisionalis (NU) yang lebih banyak konfliknya ketimbang harmonisnya. Masing-masing memiliki keyakinan, tata ritual, dan tradisi sendiri. Mereka berada di pasar. Satu lagi ialah kaum priyayi yang berpusat di kota dan memiliki keyakinan, tata ritual dan tradisi yang berbeda dan mereka kebanyakan dipengaruhi oleh tradisi Hindu Budha. Mereka ini berbeda dengan dua kategori sebelumnya karena mereka adalah wong alusan.

Tulisan yang senada dengan Geertz adalah Mulder, dalam tulisannya 
tentang "Agama, Hidup Sehari-Hari dan Perubahan Budaya". Didalam kajian yang menggunakan cara pandang lokalisasi untuk menolak konsep sinkretisasi, ia mengemukakan bahwa agama di Asia Tenggara adalah agama yang telah mengalami proses lokalisasi. Yaitu pengaruh kekuatan budaya lokal terhadap agama-agama yang datang padanya. Agama asinglah yang kemudian menyerap tradisi atau budaya lokal yang menyerap agama asing. Dalam contoh agama Islam di Indonesia, dia melihat bahwa Islam yang kemudian menyerap keyakinan atau kepercayaan lokal, sehingga yang terjadi ialah proses menarik ajaran lokal ke dalam agama-agama besar lainnya. Didalam proses lokalisasi, unsur keyakinan asing haruslah menemukan lahannya di dalam budaya lokal dan unsur asing tersebut dapat dicangkokkan. Tanpa adanya unsur lama yang serasi dengan keyakinan asing tersebut, maka keyakinan lama tidak akan dapat meresap sedemikian jauh di dalam tradisi keagamaan tersebut. Inilah sebabnya, Islam di Jawa hakikatnya adalah Islam yang telah menyerap tradisi lokal, sehingga meskipun kulitnya Islam ternyata di dalamnya ialah keyakinan lokal (Mulder, 1999: 3-18).

Menggunakan kerangka teoritik Leach tentang polysemy atau multivocality beranggapan bahwa terdapat ambiguitas simbol ritual yang berhubungan dengan variasi dan tingkatan dalam struktur sosial adalah salah satu intelektual yang membenarkan kajian Geertz tentang Islam sinkretis. Didalam kajiannya tentang Adam and Eve and Vishnu; Syncretism in the Javanese Slametan, menyatakan bahwa slametan adalah inti dari keyakinan agama Jawa popular. Di dalam slametan didapati suatu realitas meskipun mereka. berasal dari latar belakang dan penggolongan sosio kultural dan ideologi yang berbeda-beda ternyata bisa menyatu di dalam tradisi ritual slametan. Slametan juga merupakan ekpresi pandangan oposisional tentang Tuhan, wahyu, Islam dan tempat manusia di dalam kosmos. Slametan juga mengiluminasikan cara-cara di mana ritual multivokal dapat dieksploitasi didalam latar kultural yang berbeda (Beatty, 1996: 271-288).

Tulisan Geertz banyak memperoleh kritik, terutama model trikotominya yang dirasakan sebagai pemaksaan. Memasukkan priyayi berdampingan dengan santri dan abangan adalah kekeliruan konseptual, sedangkan priyayi adalah kategori sosial. Pendapat yang mirip juga datang dari Hendroprasetyo, di dalam tulisannya tentang "Mengislamkan Orang Jawa", menurutnya bahwa cara pandang Geertz seperti itu diilhami oleh cara kaum orientalis dalam memandang terhadap berbagai tradisi di masyarakat lokal yang dinyatakan sama sekali tidak ada kaitannya dengan tradisi besar diluarnya yakni Islam 
(Hendroprasetyo, 1993: 75-77). Dalam pandangannya, ada tiga tipologi mengenai kajian Islam di Indonesia, yaitu yang lebih menekankan pada aspek kesejarahan, misalnya anggapan bahwa Islam di Jawa adalah Islam sinkretik, yang disebabkan oleh adanya perbedaan antara Islam di Jawa dengan Islam di tempat lain. Cara pandang lainnya lebih menekankan pada aspek budaya lokal sebagai sebuah struktur otonom yang terlepas dari kaitan historis, sehingga yang kelihatan ialah simbol-simbol budaya lokal yang termanifestasi di dalam kehidupan masyarakat lokal termasuk dimensi keberagamaannya. Kemudian, pandangan yang juga dominan ialah penggunaan tolak ukur Islam yang selalu menekankan tradisi Timur Tengah. Dalam tulisan yang berjudul Menelusuri Dinamika Santri dan Perubahan, dinyatakan bahwa pembagian seperti itu tidak mengacu kepada kenyataan yang sebenarnya disebabkan oleh kesalahan konseptualisasi antara abangan dan santri disatu sisi, dan dengan priyayi disisi lain (Syam, 2000: 40).

Memang telah terjadi banyak perubahan didalam memandang dinamika hubungan priyayi dan santri. Kajian lain yang juga mengkritisi Geertz datang dari Hefner. Di dalam tulisannya, dinyatakan bahwa masyarakat Tengger yang secara kultural beragama Hindu/Budha, tetapi ternyata tradisi yang berkembang di sana dapat dicari asal usulnya berasal dari tradisi besar Islam yang berkembang di Jawa. Oleh karena itu, di masyarakat Tengger, ternyata terdapat hubungan antara tradisi lokal (little tradition) dengan tradisi besar (great tradition) atau Islam. Pemilahan yang ketat sepertinya sudah tidak berlaku lagi. Yang ada adalah warna agama yang khas, yang di dalamnya terdapat tarik menarik antara Islam sebagai tradisi besar dengan masyarakat setempat atau tradisi lokal (Hefner, 1985: 201).

Kritik keras juga muncul dari Muhaimin, yang menyatakan bahwa cara pandang Geertz terhadap Islam Jawa adalah cara pandang dengan semangat intelektualisme ideologi, yaitu semangat kajian Islam yang didasari oleh premis bahwa pengaruh Islam di Jawa lemah dan hanya sebatas kulit (Muhaimin, 1996: 25). Tulisannya mengenai Religion of Java dan Islam Observed adalah contoh konkrit mengenai pandangannya tersebut. Ia menyatakan bahwa cara pandang sikretisme terhadap Islam Jawa sebagaimana yang dinyatakan oleh Geertz adalah bias dari tradisi kaum kolonial yang berasumsi bahwa Islam di Jawa adalah Islam pinggiran, dan tidak menyentuh dimensi mendalam, sebab meskipun $90 \%$ beragama Islam ternyata hanya kulit luarnya saja. Muhaimin selanjutnya menggagas suatu pendekatan alternetif yang menghasilkan suatu proposisi teoritis bahwa Islam di Jawa hakikatnya ialah Islam sebagaimana 
Islam di tempat lain, yaitu Islam dalam bingkai budaya lokal.

Woodward juga melakukan kritik tajam terhadap Geertz terutama dengan kajiannya mengenai Islam Jawa. Dia menolak cara pendekatan Geertz yang dianggapnya sebagai "anti Islam" yang dapat dirujuk sampai ke cara pandang T.S Rafles dan C.S Hungrenjo. Meskipun Geertz sendiri tidak bermuatan seperti itu, tetapi wacana yang dihasilkan dari kajiannya ialah pengedepanan Islam yang tidak memiliki sumber legitimasi dari teks-teks Islam yang telah ada dan dipahami oleh orang Jawa. Pengabaian terhadap teks-teks Islam ini berakibat terhadap konsepsinya bahwa Islam di Jawa adalah Islam Sinkretik, campuran antara animism, Hinduisme dan Budhisme. Kemudian Woodward menawarkan cara pandang aksiomatika struktural, yang dengan cara ini sebagaimana penelitiannya tentang Garebeg Maulud di Yogyakarta ternyata diperoleh gambaran bahwa di pusat keraton Jawa yang dianggap paling animistis ternyata tidak dijumpai unsur tersebut. Sebaliknya dia justru melihat bagaimana Islam dan Jawa adalah sesuatu yang kompatibel, bukan antonomi (Woodward, 1991: 109-103).

Tulisan Budiwanti tentang Islam Sasak menggunakan perspektif fungsional alternative menggambarkan bahwa Islam Sasak adalah Islam juga, hanya saja Islam yang bernuansa lokal. Dalam agama Wetu Telu yang paling menonjol dan sentral adalah pengetahuan tentang lokal, tentang adat, bukan pengetahuan tentang Islam berdasarkan rumusan orang Arab. Akan tetapi juga bukan tidak menggunakan Islam sama sekali, misalnya doa-doa, tempat peribadatan masjid dan tempat lain yang mengintroduksi keIslaman mereka. Anehnya, peran Negara dalam bentuk Islam Wetu Lima menjadi sangat menonjol di tengah suasana pribumisasi Islam yang mestinya berperan akomodatif, akan tetapi justru menjadi peran penetratif yang banyak merugikan tradisi kegamaan lokal (Syam, 2005: 27).

\section{Mengislamkan Kawasan Pegunungan: Kasus di Kabupaten Pasuruan}

Adat istiadat di kawasan Tapal Kuda banyak dipengaruhi oleh budaya Madura, mengingat besarnya populasi Suku Madura di kawasan ini. Adat istiadat masyarakat Osing merupakan perpaduan budaya Jawa, Madura, dan Bali. Sementara adat istiadat Suku Tengger banyak dipengaruhi oleh budaya Hindu.

Kabupaten Pasuruan dari sudut pandang agama adalah salah satu daerah di propinsi Jawa Timur, merupakan daerah yang sangat heterogen di seluruh Jawa. Pesisir Utara kabupaten ini telah lama menjadi pusat tradisionalisme Islam dan basis Nahdlatul Ulama. Sebagaimana disebagian besar kabupaten 
lainnya yang didominasi orang Madura di perbatasan Timur Jawa Nahdlatul Ulama adalah pemenang pemilu di Pasuruan tahun 1955 dan 1971. Namun daerah Selatan, menjauh dari pesisir Utara dan menanjak ke pegunungan Tengger yang bertebing-tebing. Wilayah kultural segera berubah. Jika orang Madura dan orang Jawa keturunan Madura dominan di dataran rendah, di dataran tinggi sebagian besar adalah orang Jawa. Daerah pegunungan yang paling tinggi adalah tempat tinggal sub varian etnik penduduk Jawa secara kultural dan etnik ini dikenal sebagai Tengger, yang terkenal di seluruh Jawa karena mempertahankan secara eksplisit tradisi kependetaan non Islam sejak jatuhnya kerajaan Hindu-Budha Jawa lima abad yang lalu (Hefner, 2000; 97). Sebaliknya, lereng tengah pegunungan di tempati oleh penduduk campuran Madura dan Jawa (Jawa Dominan) yang secara tradisional terkenal karena keterkaitan mereka dengan kepercayaan terhadap roh Jawa, penentangan yang gigih terhadap NU, dan sikap acuh tak acuh yang umum terhadap cara hidup Islami yang kuat di kalangan tetangga mereka di daerah yang dataran rendah (Syam, 2005: 97).

Pada abad ke-19, sebagian besar daerah lereng tengah ini berpenduduk sedikit. Para petani Tengger tinggal dibeberapa komunitas kecil, tetapi sebagian besar pendidik yang beragama Hindu yang telah lama mengungsi di daerah pegunungan yang terpencil ini berkonsentrasi di daerah yang lebih subur dan tidak bisa dijangkau di lereng yang lebih tinggi, di sekitar Gunung Bromo, di tengah-tengah pegunungan Bromo (Hefner, 1985: 24). Perampasan budak abad ke-17 yang dilakukan raja-raja Muslim, dua abad peperangan antara kabupaten Blambangan yang Hindu di Timur dan Mataram di Barat dan selama beratus-ratus tahun penolakan terhadap Belanda dan Keraton Mataram di Jawa Tengah (Ricklefs, 2002: 44).

Berawal pada tahun 1830-an dan terus berlangsung hampir sepanjang abad itu, pesisir utara Pasuruan menjadi daerah produksi gula terbesar di Jawa. Melalui sistem tanam paksa Belanda, banyak penduduk di daerah dataran rendah ini tunduk pada permintaan tenaga kerja yang tinggi, dan akibatnya pada tahun-tahun pertama sistem itu, sejumlah besar etnik Jawa pergi ke daerah-daerah dataran tinggi dimana permintaan tenaga kerja kolonial lebih rendah. Namun, imigrasi keluar telah diganti oleh gelombang signifikan orang-orang Madura, lebih jauh lagi menggusur pengaruh kultural Jawa di daerah-daerah dataran rendah kabupaten Pasuruan. Namun, di dataran tinggi Tengger tetap dominan Jawa, sekalipun Belanda memperkenalkan tanam paksa kopi, hasil tanam paksa yang paling menguntungkan dan gelombang 
terus-menerus penduduk dataran rendah yang lebih banyak. Akhirnya imigrasi dan penanaman kopi tidak hanya mengubah ekonomi wilayah pegunungan, tetapi juga membawa fase pertama Islamisasi. Sampai pertengahan abad ke-19, sebagian besar kantong Tengger Hindu telah terdorong ke atas pegunungan atau berasimilasi dengan penduduk Muslim imigran yang dominan secara ekonomis (Hefner, 2002: 101).

Agama Islam yang dipeluk oleh sebagian besar penduduk lereng tengah adalah Islam nominal, namun mencampurkan gaya ritual Tengger dan kejawen. Menurut tetua desa dalam banyak komunitas, bahkan hingga hari ini, suatu komunitas signifikan di kalangan penduduk lereng tengah terus-menerus sampai akhir abad ke-19 mengidentifikasi dirinya bukan Islam dan sebagaimana di Tengger, beberapa laki-laki masih menolak khitan. Banyak orang Hindu Tengger modern dewasa ini dilarang berkhitan. Tidak ada langgar, masjid, dan pesantren sampai tahun 1910, ketika pembangunan jalan itu menghasilkan peningkatan aktivitas perdagangan dan imigrasi besarbesaran di daerah dataran rendah. Didalam kebanyakan komunitas, imigran yang datang belakangan inilah yang menyediakan modal dan inspirasi bagi pembangunan tempat-tempat ibadah, namun kebanyakan imigran laki-laki mengambil perempuan lokal sebagai istri dan banyak yang akhirnya menerima sikap keagamaan yang tidak begitu ortodoks. Suatu pola umum adalah bagi laki-laki yang telah memperoleh kekayaan mereka dalam perdagangan, mengkonsolidasikan klaim mereka terhadap status di desa-desa dataran tinggi dengan memperoleh tanah dan melakukan apa yang pantas atas semua orang kaya dan berstatus di wilayah pegunungan ini mensponsori acara selamatan yang dipersembahkan kepada arwah leluhur desa, pelindung daerah, dan roh-roh tanah dan air pegunungan.

Perayaan-perayaan seperti itu seperti penyediaan makanan untuk beratus-ratus tamu, tayuban, pentas ketoprak, dan sebelum dan di atas semuanya penyajian sesajen kepada roh pelindung di makam para leluhur desa dan periperi air. Meskipun beberapa perbedaan dalam rincian perayaan dan perbedaan yang lebih luas dalam bentuk ritual keagamaan, kepedulian ritual yang sama merupakan fokus kepercayaan rakyat Hindu Tengger. Mayoritas muslim di wilayah pegunungan lereng tengah menolak bentuk-bentuk kesalehan Islam yang lebih ketat, yang mereka identifikasi dengan kebudayaan ngare yang tidak njawani dan terstratifikasi secara ketat, yakni "orang dataran rendah".

Penting untuk diingat bahwa islamisasi telah berkaitan dengan kekuatan sosiopolitik yang sangat berbeda. Pada abad ke-19 dan awal abad ke-20, ia 
bergandengan tangan dengan berkembangnya pesantren, sekolah-sekolah agama, dan stuktur ekonomi, dimana tradisi keagamaan alternatif dan struktur sosial secara perlahan-lahan terbangun.

\section{Mistifikasi, Sakralisasi dan Mitologi Masyarakat Jawa}

Masyarakat desa di Jawa Timur, seperti halnya di Jawa Tengah, memiliki ikatan yang berdasarkan persahabatan dan teritorial. Berbagai upacara adat yang diselenggarakan antara lain: tingkepan (upacara usia kehamilan tujuh bulan bagi anak pertama), babaran (upacara menjelang lahirnya bayi), sepasaran (upacara setelah bayi berusia lima hari), pitonan (upacara setelah bayi berusia tujuh bulan), sunatan, pacangan. Selain itu, masjid, makam dan sumur adalah lokus penting dalam prosesi upacara pada masyarakat pesisir. Ketiganya menjadi tempat-tempat sacral yang mestilah menjadi tempat penting di dalam kehidupan masyarakat. Sebagai medan budaya, ketiganya memiliki keunikan sendiri, yakni sebagai tempat yang memiliki nuansa atau aura yang berbeda dengan yang profane atau duniawi. Disinilah masyarakat melakukan kegiatan ritual untuk memperoleh barakah (dalam bahasa Arab) yang mengalami desimilasi menjadi berkah (dalam bahasa Jawa). Apapun namanya, yang jelas bahwa motif penyebab di antara mereka yang menyelenggarakan berbagai ritual adalah keinginan kuat untuk memperoleh rahmat dan kebahagiaan. Prosesi penyelenggaraan upacara disebut sebagai selamat, berasal dari Bahasa Arab salama yang mengalami desimilasi menjadi slamet, maknanya adalah memperoleh keselamatan. Jadi, baik proses maupun hasil akhir dari rangkaian upacara adalah memperoleh keselamatan dan kebahagiaan. Oleh karena itu in order to motive atau motif tujuan dari rangkaian kegiatan itu adalah keinginan yang kuat untuk memperoleh keselamatan.

Untuk memperoleh keselamatan tersebut, berbagai upacara dilakukan mulai dari upacara lingkaran hidup, upacara kelenderikal, upacara tolak balak dan upacara hari-hari penting. Upacara tersebut dilakukan di rumah atau di luar rumah. Upacara kelenderikal dan sebagian upacara lingkaran hidup dilakukan di masjid. Sedangkan upacara-upacara kalenderikal kebanyakan dilakukan di masjid. Sedangkan upacara tolak balak, dapat dilakukan di rumah, di sumur atau di makam. Selain upacara tersebut, upacara penting yang dilakukan secara berkelanjutan adalah upacara di makam atau di sumur. Upacara di makam adalah upacara manganan dan atau khaul, sedangkan upacara di sumur adalah upacara nyadran atau sedekah bumi. Sebagaimana telah dijelaskan di depan, bahwa lokus (sumur, makam dan masjid) dianggap 
suci karena beberapa alasan. Sumur dianggap sakral karena dibuat oleh para wali atau disebut sebagai sumur wali, Masjid juga dianggap sakral karena peninggalan wali dan makam dianggap sakral karena makam wali.

Penempatan sumur, makam dan masjid sebagai tempat sakral adalah pemikiran yang didasari oleh mitologi. Artinya bahwa kesakralan itu "dimitoskan". Memang didalam kehidupan ini tidak semuanya bisa dianggap sebagai realitas yang profane, akan tetapi juga terdapat wilayah atau lokus yang dianggap sebagai sakral. Untuk menjadi sakral itu, harus memenuhi persyaratan sebagai sesuatu yang sakral, yaitu: pertama, ia memang sesuatu yang pantas disakralkan dan kesakralannya itu melekat pada benda itu. Tidak semua makam dan sumur dianggap sakral karena tidak memenuhi persyaratan sebagai sakral. Bagi sebagian umat Islam, makam dianggap sakral kalau ia adalah makam orang yang pantas disakralkan, seperti wali atau penyebar Islam yang diyakini memliki kelebihan-kelebihan suprantural (Abdullah, 1988: 6-7).

Dalam cerita-cerita selalu ada tokoh-tokoh mitos yang dengan kekuatan supranaturalnya dapat mengubah sesuatu menjadi sesuatu yang lain. Sunan Bonang dapat mengubah sesuatu menjadi sesuatu yang lain. Sunan Bonang dapat mengubah buah kelapa menjadi koin emas, Maulana Iskhak dapat menyembuhkan putri Blambangan dengan kekuatn ghaib, Sultan Agung dapat berjamaah di Mekkah, dan sebagainya. Dalam dunia mitologi, sosok manusia bisa menjadi manusia lebih, sebongkah benda juga bisa menjadi sebongkah benda lebih. Manusia atau benda yang dimitoskan itu kemudian hidup dalam sejarah-sejarah lisan melalui proses pelembagaan, habitualisasi dan legitimasi. Biasanya melalui proses yang diciptakan oleh kaum elit, terutama dalam proses kekuasan.

Jadi, memitologikan makam, masjid dan sumur juga melalui legitimasi kekuasaan. Misalnya untuk makam wali, biasanya oleh para juru kunci atau abdi makam, untuk masjid dapat melalui takmir masjid dan untuk sumur melalui tokoh-tokoh lokal yang berkepentingan terhadap pelestarian tradisi tersebut. Mistifikasi terjadi jika manusia atau benda memiliki kekuatan yang diyakini sebagai kekuatan lebih dibanding manusia atau benda lainnya. Misteri tersebut, misalnya terdapat pada sosok manusia yang memiliki kelebihan di bidang tertentu yang sifatnya supranatural. Jadi bukan kelebihan yang bersifat natural. Kelebihan itu berada di luar sifat kemanusiaan lainnya. Para wali itu memiliki mistifikasi masing-masing. Misalnya, sesama dianggap wali, tetapi misterinya berbeda-beda. Sunan Bonang memiliki misteri yang lebih besar dibanding dengan Syaikh Ibrahim Asmawqandi (Syam, 2005: 261). Padahal 
Syaikh Ibrahim adalah kakeknya. Sesama putra Sunan Ampel, tetapi ada yang memiliki misteri lebih besar di banding lainnya. Sunan Bonang lebih besar mistifikasinya dibandingkan dengan Sunan Lamongan atau Syaikh Hisamuddin dan seterusnya.

Mistifikasi pun memerlukan ruang untuk dapat bertahan. Salah satu di antara cara untuk mempertahankan mistifikasi itu adalah proses pelembagaan cerita-cerita keunggulan yang dimiliki oleh wali dimaksud. Misalnya, mimbar dan ruang imaman masjid Syaikh Ibrahim akan terus dilestarikan meskipun masjid itu telah mengalami perubahan demi perubahan. Menara masjid Asyhariyah, masjid Ibrahim, masjid Bonang dan seterusnya juga akan tetap dipertahankan di tengah keinginan untuk memugar masjid tersebut menjadi baru dan modern. Bahkan bekas kayu-kayu masjid juga akan disertakan dalam pembangunan masjid yang baru jika masjid tersebut di pugar. Entah dengan alasan agar tetap ada keberkahan bagi pembuat masjid pendahulu, akan tetapi yang jelas adalah untuk mempertahankan mistifikasi masjid tersebut.

Pandangan tentang mistifikasi dan mitologi terhadap makam, sumur dan masjid hakikatnya adalah menempatkan alam sebagai subjek. Alam memiliki aura keunikan, misteri dan kekuatan, sehingga dengan keadaan seperti itu, alam harus ditempatkan dalam dan menjadi fenomena yang bukan profan. Alam bukan dunia multatis muntandis atau ipso facto. Akan tetapi alam adalah subjek yang dapat mengatur, menjaga dan menumbuh kembangkan sesuatu yang lain. Makam bisa memancarkan berkah, sehingga orang harus membuat sesuatu yang menyebabkan akan munculnya berkah tersebut. Sedangkan pandangan tentang demistifikasi dan demitologi tentang alam, hakikatnya adalah kecenderungan berfikir orang modern yang menganggap alam adalah objek. Alam dapat dimanfaatkan untuk kepentingan manusia dan bukan alam memanfaatkan manusia. Alam bukan pengatur, penjaga apalagi menumbuh kembangkan sesuatu, alam adalah yang diatur, dijaga atau ditumbuhkembangkan. Alam adalah bagian dari dunia yang dapat dimanfaatkan secara maksimal oleh manusia. Pandangan terhadap remistifikasi dan remitologi muncul ketika orang mulai melihat kembali dunia spiritualnya yang hilang. Terlalu menganggap alam bahwa alam adalah semata-mata objek akan menyebabkan kurangnya penghargaan manusia terhadap alam. 


\section{Simpulan}

Fenomena tentang kearifan lokal dalam kehidupan keberagamaan adalah suatu keniscayaan, mengingat dalam sistem budaya masyarakat terdapat suatu sistem dan keyakinan tertentu pada diri mereka. Ketika seseorang mendengar istilah "Agama Jawa" disebut orang, serta-merta terlintas suatu gambaran tertentu tentang tradisi yang berkembang dalam komunitas Jawa tertentu yang terbedakan secara jelas dari agama, khususnya Islam, yang juga perkembangan berdampingan dengannya. Artinya, dalam "Agama Jawa" itu terdapat suatu pandangan hidup (world view) yang terdiri dari sistem kepercayaan, peribadatan, sakralisasi, mitologi dan lain-lain, yang secara keseluruhan disebut dengan "Agama Jawa," dan itu bukan Islam, bukan Kristen atau Katholik, bukan Hindu, juga bukan Budha.

Kalaupun dalam The Religion of Java, Clifford Geertz mengemukakan trikotomi Santri, Priyayi, dan Abangan, sebenarnya varian Santri tidak mungkin dapat dimasukkan dalam kategori "pemeluk" Agama Jawa, tetapi lebih tepat jika disebut sebagai pemeluk Islam yang bersuku Jawa. Sebab, dalam religiusitasnya, mereka lebih menampakkan kesantriannya ketimbang kejawaannya.

Pasuruan menantikan suatu contoh perbandingan etnografis dengan daerah pedesaan Jawa yang lain. Bila perkembangan serupa terjadi dibeberapa sektor lain komunitas Jawa, maka kemungkinan ada kekuatan organisasi stuktural yang telah memberikan keseimbangan kekuatan budaya antara Islam dan kejawen, bagaimanapun juga itu merupakan upaya Islamisasi Jawa.

\section{Daftar Pustaka}

Abdullah, Taufik. 1988. Mitos, Kewibawaan dan Perilaku Budaya. Jakarta: Pustaka Grafika Kita.

Artawijaya. 2010. Jaringan Yahudi Internasional di Nusantara. Pustaka Al-Kautsar: Jakarta.

Beatty, Andrew. 2001. Variasi Agama di Jawa: Suatu Pendekatan Antropologi. PT. Raja Grafindo Persada. Jakarta.

Beatty, Andrew. 1996. "Adam and Eve and Vishnu: Syncretism in The Javanese Slametan. Dalam The Jurnal of Royal Antropological 2.

Boland, B.J. 1982. The Strunggle of Islam in Modern Indonesia. Den Haag: Martinus Nijhoff. 
Bowie, Fiona. 2000. The Antropology of Religion An Introduction. Oxford: Blacwell Publisher.

Dhavamony, Mariasusai, 1977. Fenomenologi Agama. Yogyakarta: Kanisius.

Dhofier, Zamakhsyari. 1982. Tradisi Pesantren: Studi tentang Pandangan Hidup Kiai. Jakarta: LP3ES.

Dirks, Nicholas B. 1994. "Ritual and Resisteance: Subverstion as Social Fact". Dalam Nichols B. Dirkc, et.al, (ed), Cultur/Power/History, A Reader in Contemporary Social Theory. Princeton: Priceton University Press.

Geertz, Clifford. 1960. The Religion of Java. Glencoe: The Free Press

Geertz, Clifford. 1981. Santri, Priyayi, Abangan dalam Masyarakat Jawa. Jakarta: Pustaka Jaya.

Hefner, Robert W. 1985. Hindu Javanese: Tengger Tradition and Islam. Princeton: Pricenton University Press.

Hefner, Robert W. 2000. Islam Pasar Keadilan: Artikulasi Lokal, Kapitalisme dan Demokrasi. Yogyakarta: LKiS.

Hendroprasetyo, 1993. "Mengislamkan Orang Jawa: Antropologi Baru Islam Indonesia. Dalam Islamika. No. 3.

Koentjaraningrat, 1985. Pokok-pokok Antropologi Sosial. Jakarta; Dian Press.

Malinowsky Barton, 1985. Antropological Approach to The Study of Religion. London: Tavistock Publication.

Muhaimin, AG. 2001. 1996. "Pendekatan Multidisipliner, Metode Penelitian Agama dan Paradigma Antropologi." Dalam Eko Aliroso (ed.), Beberapa Paradigma dalam Penelitian Agama Berikut Konsekuensi Metodologis. Jakarta: Balitbang Depag RI.

Muhaimin, AG. 2001. Islam dalam Bingkai Budaya Lokal Potret dari Cirebon. Jakarta: Logor.

Mulder, Niels. 1999. Agama, Hidup Sehari-hari dan perubahan Budaya. Jakarta: Gramedia Pustaka Utama. 
Ricklefs, M.C. 2002. "Syeckh Al-Mutamakin dan Sejarah Jawa Abad XVIII." Dalam Abdul Milal Bizawie. Perlawanan Kultural Agama Rakyat. Yogyakarta: SAMHA.

Syam, Nur. 2000. "Menelusuri Dinamika Santri dan Perubahan." Dalam Majalah Araaita. Ed. 40/Th. XIX.

Syam, Nur. 2005. Islam Pesisir. Yogyakarta: LKiS.

Baal, Van, J. 1995. Antropologi Budaya. Jakarta: Gramedia Pustaka.

Winnick. 1977. Islam in Java: Normative Piety and Myticism. Tucson: University of Arizona Press.

Woodward, Mark R. 1991. The Grebed Maulud in Yogyakarta: Veneration od The Prophet as Imperial Ritual". Dalam Journal of Ritual Studies. 